\title{
PRÁTICA DE LETRAMENTO POÉTICO DE CANÇÕES FEMININAS
}

\author{
Joseneide Santos de Jesus ${ }^{1}$ \\ Carlos Magno Gomes ${ }^{2}$
}

\begin{abstract}
Resumo: Este artigo descreve uma proposta de intervenção para formação de leitores/as críticos/as por meio de canções de autoria feminina que destacam o empoderamento da mulher na luta contra a desigualdade de gênero. Debatemos as especificidades do letramento poético e a performance feminista a partir de duas oficinas voltadas para a educação básica, explorando as canções "Respeita”, de Ana Cañas, e "Respeita as mina", de Kell Smith. Metodologicamente, articulamos, na fundamentação desta abordagem, os conceitos de ensino de poesia, de Hélder Pinheiro Alves, hibridismo estético das canções, de Simone Alcântara, e performance vocal, de Paul Zumthor. Quanto ao empoderamento feminino e o lugar de falar da mulher, ressaltamos os questionamentos feministas de Djamila Ribeiro e Chimamanda Adichie, que destacam a importância da revisão das normas de gênero para a valorização da igualdade de direitos entre homens e mulheres.
\end{abstract}

Palavras-Chave: Letramento poético. Performance feminina. Empoderamento da mulher. Canção popular.

\section{PRACTICE OF POETIC LITERACY OF FEMALE SONGS}

\begin{abstract}
This article describes an intervention proposal for the training of readers and critics through songs written by women that highlight the female empowerment in gender inequality struggle. There will be discussed the specificities of poetic literacy and feminist performance regarding two workshops focused on basic education, exploring the songs "Respeita", by Ana Cañas, and "Respeita as mina", by Kell Smith. Methodologically, in the foundation of this approach, the concepts of poetry teaching, by Hélder Pinheiro Alves, aesthetic hybridism of songs, by Simone Alcântara, and vocal performance, by Paul Zumthor are articuled. As for female empowerment and standpoint, we highlight the feminist questions brought by Djamila Ribeiro (and the concept of "place of speech") and Chimamanda Adichie, which highlight the importance of revising gender norms for the valorization of equal rights between men and women.
\end{abstract}

Keywords: poetic literacy. Female performance. Empowerment of women. Popular song.

\footnotetext{
${ }^{1}$ Mestra em Letras pelo Profletras da Unidade de Itabaiana. Professora da Rede Estadual da Bahia. Bolsista CAPES (2017-2019). E-mail: josynj.21@gmail.com.

2 Prof. Dr. de teoria literária da UFS. Pesquisador Produtividade do CNPq vinculado ao Profletras da Unidade de Itabaiana e ao PPGL. E-mail: calmag@bol.com.br.
} 
O casamento como destino para uma mulher baseia-se nos preceitos da dominação masculina, uma vez que a subordinação do gênero feminino ao masculino normalmente aparece como algo inquestionável em sociedades patriarcais e machistas. Chimamanda Adichie nos lembra que, especialmente com as meninas, não devemos falar do casamento como realização pessoal. Esse acontecimento pode ser algo muito bom, que pode até ser complementar à sua felicidade, todavia não se trata de uma realização, pois a mulheres são condicionadas a "aspirarem ao matrimônio e não fazemos o mesmo com os meninos; assim, de partida, já há um desequilíbrio tremendo" (ADICHIE, 2017, p. 16).

Na acepção da antropóloga Lia Zonatta Machado, essa normatização de gênero é naturalizada para ser aceita como padrão, proporcionando diversos tipos de violência contra a mulher. Essa opressão nem sempre gera conflito de forma direta, mas é composta de valores que aprisionam as mulheres à virilidade masculina e à ideia de proteção. Tais valores fazem parte de um repertório de violência de gênero, regulamentado pelo poder masculino de "controlar, fiscalizar e fazer obedecer as mulheres, impondo assim sua vontade quer seja por agressão físico-moral ou apenas moral (MACHADO, 2017, p. 42).

Partindo do contexto social de uma pequena cidade do interior da Bahia, na qual o papel da mulher ainda é condicionado a viver do lado de um homem, propomos uma prática de letramento poético de canções femininas que visa promover o desenvolvimento de habilidades de leitura crítica e reflexiva de alunos/as do nono ano do ensino fundamental de uma escola da rede municipal de Jeremoabo/BA. A referida escola está inserida em uma comunidade onde é muito comum as jovens se casarem muito cedo, entre os 14 e 17 anos. Quem não encontra um companheiro até 20 anos é criticada, pois, na visão das pessoas dessa comunidade, a mulher deve aceitar seu destino se casando.

Diante deste cenário, propomos uma prática de letramento poético de canções que abordem o lugar de fala da mulher e seu empoderamento. Tal letramento passa pelo exercício de ir além do universo textual e explorar os sentimentos que a poética nos convida a exercitar. Didaticamente, dividimos esta prática em três seções: abordagens teóricas, que dão sustentação à prática de letramento de canções pela perspectiva feminista; seguida da proposta de 
oficinas compostas por canções como textos multimodais e híbridos, videoclipes, publicidades, documentários, entre outros; por fim, as considerações críticas sobre esta proposta com análise dos dados da prática.

Para este texto, vamos trazer o recorte do corpus das canções que apresentam ideias de empoderamento feminino e questionamento do machismo, presentes em: "Respeita", de Ana Cañas, e "Respeita as mina”, de Kell Smith. Essas artistas ressaltam a criatividade feminina e a resistência como forma de desconstrução do poder masculino. No projeto original, nossa prática foi dividida em três etapas com um repertório dinâmico de produções de artistas jovens como também das cantoras mais experientes ${ }^{3}$. As principais fundamentações teóricas sobre o letramento poético são sustentadas pelos conceitos de Pinheiro (2018) e Alcântara (2012), enquanto as reflexões feministas são fundamentadas pelo debate crítico proposto por Djamila Ribeiro (2017), acerca do ponto de vista feminista, e por Chimamanda Adichie (2017) sobre a desconstrução da normatização de gênero.

Tal prática pretende ir além do letramento de canções e propõe romper o paradigma do casamento cedo, promovendo reflexões de gênero e destacando que o papel social da mulher não se reduz aos cuidados do lar e de um companheiro. Nesse contexto, o papel do letramento literário é bem mais amplo, pois estamos pensando em desenvolver o gosto pela leitura e pela formação crítica desse/a leitor/a para questionar valores da violência estrutural imposta às mulheres. Para isso, propomos uma abordagem interpretativa baseada nos estudos de gênero para analisar como a mulher é representada em canções de cantoras brasileiras contemporâneas. Nossa prática analisou tanto canções da MPB como do rock e do pop, nessas canções, as vozes femininas líricas abordam, expõem, questionam e denunciam aspectos da vida cotidiana da mulher de maneira intimista e, ao mesmo tempo, crítica.

Cabe destacar que o gênero canção está sendo usado por sua condição híbrida e fronteiriça, visto que esse gênero artístico é composto de diferentes

\footnotetext{
${ }^{3}$ No projeto original, montamos três oficinas com estrutura: 1 - análise das performances artísticas de "Paradinha", de Anitta e "Cheguei", de Ludmila, questionando o sensualidade e estrelismo social; 2 debate sobre empoderamento feminino e questionamento do machismo: "Desconstruindo Amélia", de Pitty, e "Respeita", de Ana Cañas; e 3 - ampliação do horizonte de expectativas para valorizar lugar de fala da mulher: "Pagu", de Zélia Duncan e Rita Lee e "Balacobaco", de Rita Lee.
} 
parâmetros de linguagens que "traduzem a experiência poética do artista e a dos ouvintes, ou seja, expressam sentidos pessoais, sociais, culturais e estéticos propostos, em conjunto, por uma obra - sentidos em todos os sentidos" (ALCÂNTARA, 2012b, p. 9). Portanto, nossa intenção é de nos apropriarmos da riqueza multissemiótica e performática que a canção pode apresentar para motivar os participantes desta prática a ampliarem seu horizonte cultural. Para tanto, priorizamos o método cultural de leitura, defendido por Gomes “como uma opção política de interpretação para dar visibilidade às questões identitárias por meio da recepção textual” (2014, p. 168). Com isso, pretendemos articular o ponto de vista feminista e a identificação com o lugar de resistência proposto pelas compositoras das canções.

Na sequência, apresentamos algumas reflexões teóricas sobre a importância do letramento de canções, seguidas de aportes sobre a relevância do pensamento feminista para o questionamento das normas de gênero.

\section{O/a leitor/a de canções e o empoderamento feminino}

A poesia desperta nossa subjetividade sensitiva e intelectual por, normalmente, exigir uma leitura mais atenta e concentrada. As palavras no texto poético não têm compromisso direto com a objetividade. Elas podem ser exploradas por suas nuances plurissignificativas, que, no processo de recepção, se intensificam a partir das experiências do/a leitor/a, pois o texto não tem existência sem as instâncias interpretativas e colaborativas do sujeito que ler. Especificamente, a canção, por ser um gênero textual híbrido, já que associa som, letra, imagem, entre outros elementos, é um excelente recurso para as aulas de leitura, visto que tem uma ótima recepção por parte dos/as alunos/as em diversos segmentos de ensino.

A canção é tratada neste trabalho com o enfoque de representação da arte. Não se trata de trabalhar esse gênero apenas tratando-o como objeto estético e analisando as suas relações com o poema apenas em nível estrutural e estético. Trabalharemos a relação da canção com a poesia num sentido mais amplo para possibilitar o diálogo entre as mensagens que se deseja transmitir em cada texto. Nosso objetivo não está em trabalhar apenas o gênero textual 
e/ou literário, mas sim debater sobre a performance artística que cada canção traz, dando destaque ao empoderamento feminino e aos direitos da mulher.

Para tanto, é preciso diversificar as práticas de se trabalhar com a poesia porque em muitas delas ainda é possível observar que não há “uma aproximação mais afetiva do texto, a possibilidade de destaque para uma imagem, um ritmo diverso, uma sonoridade" (ALVES, 2008, p. 20). Cabe destacar que a canção apresenta abrangentes possibilidades para serem debatidas por ser híbrida e democrática visto que "transita das rádios mais populares aos Ipods mais sofisticados, de shows abertos a teatros tradicionais, bem como das telenovelas aos documentários de arte" (ALCÂNTARA, 2012a, p. 28).

A canção, independentemente da sua classificação (MPB, rock, sertanejo, pop, pagode...), é um gênero literário que está presente na vida das pessoas, especialmente dos/as jovens e adolescentes, de maneira muito intensa. Além do mais, é possível "plantar um quinhão de curiosidade ante às tantas riquezas de sentido que podem nascer do encontro do leitor com o texto em verso" (ALVES, 2008, p. 20). Esse convite para o letramento lírico torna-se engajado quando selecionamos canções de artistas brasileiras que questionam os estereótipos femininos e o machismo ainda comum na produção cultural brasileira.

Como estamos preocupados com a voz da mulher, destacamos que há poucas antologias que favorecem uma abordagem de ensino do texto poético feminino. Por isso, torna-se necessário a ampliação do corpus de poetas com a inclusão das compositoras, pois as "vozes femininas" ainda são inferiores ao número de poetas nas coletâneas escolares, "aspecto indicativo do silenciamento e da exclusão das vozes líricas femininas" (ALVES; NEVES, 2017, p. 92). Sendo assim, introduzir produções artísticas das compositoras representa, por si só, a ampliação do cânone escolar com textos multimodais e multissemióticos.

A dinâmica da canção demanda uma prática de letramento que explore as diferentes linguagens desse gênero oral, que demanda uma performance artística híbrida. Para Paul Zumthor, a recepção da canção abrange mais que seu suporte verbal ou vocal, pois inclui diversos outros aspectos exteriores que interferem diretamente na compreensão textual. 
Com efeito, nas formas poéticas transmitidas pela voz (ainda que elas tenham sido previamente compostas por escrito), a autonomia relativa do texto, em relação à obra diminui muito: podemos supor que, no extremo, o efeito textual desapareceria e que todo o lugar da obra se investiria dos elementos performanciais, não textuais, como a pessoa e o jogo do intérprete, o auditório, as circunstâncias, o ambiente cultural e, em profundidade, as relações intersubjetivas, as relações entre a representação e o vivido (ZUMTHOR, 2018, p. 18).

Para nossa proposta de letramento literário por meio de canções, é indispensável englobarmos essa dinâmica desse gênero e explorar a produção performática dos videoclipes. A seleção desse gênero também foi estrategicamente pensada para motivar os/as participantes a se engajarem com a divulgação da literatura oral, explorando temas que fazem parte de sua comunidade. Vale lembrar que esse gênero textual faz parte do imaginário cultural brasileiro, e apresenta diversos exemplos de ruptura de fronteiras, visto que "sempre de uma forma lúdica, a nossa canção vai (en) cantando o público nacional e internacional, das letras à palavra, dos sons à voz, à melodia, à performance e à tecnologia (ou seria em sentido inverso?), para, dessa maneira, compor a poesia nossa de cada dia" (ALCÂNTARA, 2012a, p. 28).

Nessa perspectiva, a performance feminina de resistência não está apenas na letra da música, mas também na performance da artista. Com isso, a canção nos convida a sair do lugar comum e ampliarmos nosso horizonte cultural, pois valorizamos a canção e a capacidade do/a leitor/a de se apropriar de seus sentidos para experienciá-los a partir de seu contexto social: “Não há recepção textual desvinculada da pessoa que lê, da atuação do/a intérprete, do público, do momento e dos elementos culturais. Por isso, há relação direta entre a "recepção do texto poético com o corpo vivo" (ZUMTHOR, 2018, p. 27).

Assim, ao priorizamos a temática do empoderamento feminino, reforçamos os diferentes diálogos entre a canção e o contexto dos participantes. Com isso, promovemos um debate em torno dos direitos da mulher e da busca por emancipação, pois para o letramento cultural, um/a leitor/a é "aquele que inclui no processo de interpretação as questões identitárias: gênero, raça, sexualidade” (GOMES, 2014, p. 10). Além disso, essa 
abordagem prioriza o processo de interpretação, levando em conta as relações entre leitor e contexto social e tem a finalidade "de mostrar o quanto a leitura literária pode se tornar uma leitura social quando explora os elementos estéticos e culturais de forma politizada" (GOMES, 2010, p. 9).

A forma como essas canções são recepcionadas é fundamental para uma prática de empoderamento feminino, pois "a voz viva tem necessidade uma necessidade vital - de revanche, de "tomar a palavra", como se diz" (ZUMTHOR, 2018, p. 17). Assim, debatemos a importância de a mulher falar de si mesma, de expor seu ponto de vista sobre as diferentes formas de violência. No tocante à questão da voz, do lugar de fala, é imprescindível esse debate para analisarmos as percepções sensoriais e críticas que emanam do texto.

Nesse sentido, formar um/a leitor/a tem relação direta com a formação do/a cidadão/ã, reforçando o compromisso e a responsabilidade da escola nesse processo. Annie Rouxel defende que "A cultura literária tem sentido para o sujeito quando a obra lida é relacionada com a experiência do mundo" (2013, p. 180). Sendo assim, o trabalho com as canções justifica-se pela importância do tema, visto que as relações de gênero na sociedade ainda são regulamentadas por normas que privilegiam a desigualdade de gênero. Com esse recorte, abrimos espaço para a formação do sujeito que seja capaz de fazer da leitura estética uma maneira de conhecer a si mesmo e de ser transformado pelo texto (ROUXEL, 2014, p. 21).

Quanto aos papeis de gênero, Adichie argumenta que desde cedo as crianças, especialmente as meninas, precisam aprender "que "papéis de gênero" são totalmente absurdos. Nunca lhe diga para fazer ou deixar de fazer alguma coisa "porque você é menina" (2017, p. 10). Discutir essa concepção com as crianças e adolescentes é uma alternativa para desconstruir a imagem de que alguém deve fazer ou deixar de fazer algo simplesmente pelo fato de ser mulher ou homem. É inadmissível uma pessoa ser impedida de acessar espaços de cidadania simplesmente porque a sociedade dita que ela não pode pelo simples fato de ter nascido mulher.

Ao propor um trabalho de conscientização do lugar de fala da mulher ressaltamos que a luta feminista não pode retroceder. Mesmo que os avanços sejam a passos lentos, uma vez que "vozes dissonantes têm conseguido produzir ruídos e rachaduras na narrativa hegemônica, o que, muitas vezes, 
desonestamente, faz com que essas vozes sejam acusadas de agressivas justamente por lutarem contra a violência do silêncio imposto" (RIBEIRO, 2017, p. 87). Logo, é necessário enfrentar os falsos empoderamentos que impõem uma agenda neoliberal e fascista para explorar a liberdade da mulher. Do contrário, estaríamos acreditando num "falso empoderamento, que só se presta às necessidades mais superficiais de um grupo específico de mulheres as mais privilegiadas" (LARA et al., 2016, p. 75).

Para tanto, é preciso que se incentive a questionar a linguagem que dá sustentação discursiva a essa situação porque "A linguagem é o repositório de nossos preconceitos, de nossas crenças, de nossos pressupostos. Mas, para lhe ensinar isso, você terá de questionar sua própria linguagem" (ADICHIE, 2017, p. 14). Sendo assim, nós educadores/as temos um papel fundamental, pois não basta falarmos para os/as nossos alunos/as que precisamos desconstruir o padrão de normatizar a pessoa pelo gênero que representa, mas agir e tratálos/as sem rotulá-los/as também.

Nesse contexto, é fundamental discutir qual seria de verdade o tipo de empoderamento que buscamos. Habitualmente a mulher empoderada é associada a determinado status de beleza (normalmente de pele branca), à vaidade e à condição financeira. Sendo assim, quem não se enquadra a esses padrões não pode ser empoderada? Nesse contexto, para uma mulher empoderar-se e/ou ter sucesso na vida pessoal e profissional não basta que ela tenha determinação e iniciativa para alcançar os seus objetivos.

Para entendermos o questionamento da violência de gênero, exploramos diferentes intertextualidades para ampliarmos o horizonte cultural dos participantes. Para tanto, selecionamos discussões jurídicas para fundamentarmos o debate a partir de reflexões sobre a lei Maria da Penha (2006). Tal perspectiva propõe a ruptura do paradigma de mulher submissa e homem provedor. Essa prática de classificar e normatizar as relações sociais provoca instabilidades e conflitos, visto que "a forma violenta advinda da desigualdade de gênero advém da legitimidade de longa duração do poder masculino como poder patriarcal de controlar e fazer obedecer às mulheres" (MACHADO, 2017, p. 42). 
Na sequência, apresentamos de forma sucinta uma das oficinas programadas para esta experiência. Logo depois, analisaremos os resultados provenientes dessa experiência com canções de autoria feminina.

\section{Oficina de empoderamento feminino}

Nesta oficina foram trabalhadas as canções “Respeita”, de Ana Cañas, e "Respeita as mina”, e Kell Smith. Nas canções o eu-lírico clama por respeito ao seu corpo, ao direito de andar sozinha sem ser assediada, visto que estar por aí não significa estar à toa, já que para o pensamento machista, uma mulher andar desacompanhada em alguns ambientes pode significar que ela está disponível e que aceita ser assediada. Os videoclipes das músicas também trazem a representação de diversas mulheres que mostram o seu rosto e reforçam as reivindicações do texto. Nessa perspectiva, a recepção explora a natureza plural da poesia, que "é encontro e confronto pessoal, a leitura é diálogo. A "compreensão" que ela opera é fundamentalmente dialógica: meu corpo reage à materialidade do objeto, minha voz se mistura, virtualmente, à sua" (ZUMTHOR, 2018, p. 59).

Para a realização dessa atividade, após assistirem aos videoclipes, pautamo-nos no posicionamento dos teóricos do texto poético que nos aconselham o uso de atividades que valorizem a voz alta em sala de aula, pois essa prática "é um instrumento importante para uma aproximação ao poema e, no contexto da sala de aula, quando bem realizada, pode despertar o interesse de muitos leitores" (PINHEIRO, 2018, p. 32). O uso da voz também foi explorado como instrumento de reinvindicação social, de luta e disputa de espaços porque "Necessariamente, parece-me, a voz viva tem necessidade - uma necessidade vital - de revanche, de tomar a palavra", como se diz (ZUMTHOR, 2018, p. 17).

Inicialmente, explicamos nossa abordagem que privilegia a voz da mulher na canção, pois estamos interessados em tratar essa prática como uma "produção estético-cultural, marcada pelas diferenças ideológicas que fazem parte da construção textual e da recepção crítica" (GOMES, 2012, p. 168). Assim, antes de realizar a leitura os/as discentes serão convidados/as a refletir sobre o contexto de protesto que a canção traz para repensarmos porque ela questiona a violência e propõe a resistência feminina. 
Nesse debate, lembramos que essa luta é contínua, pois os direitos da mulher continuam sendo ameaçados todos os dias. Lia Zanotta Machado argumenta que, apesar de ainda faltar uma adequada implementação das leis na sociedade brasileira, elas são de grande importância porque

\begin{abstract}
A Lei propõe para sujeitos homens e mulheres que chegam aos Juizados, não somente o entendimento do ato de violência como ilegal e ilegítimo, assim como propõe como possível uma modelagem simbólica da construção de relações de reciprocidade de gênero no âmbito doméstico onde diferenças de estilo e conflitos persistem, mas relações desiguais de poder entre gêneros deixam de ser "valores legitimados (MACHADO, 2017, p. 40-41).
\end{abstract}

Um dos pontos debatidos, além da importância de ressaltar a voz da mulher, passou pela revisão do ponto de vista machista que atribui à vítima a culpa pela violência sofrida. Essa é uma estratégia da sociedade e/ou do agressor de naturalizar formas de violência e de tentar justificar atos injustificáveis, pois "A mulher que está em uma relação abusiva precisa repetir para si mesma: a culpa nunca é da vítima. NUNCA" (LARA et al., 2016, p. 189).

Ao retomar o debate sobre a violência contra a mulher, devemos priorizar a revisão desse padrão, já que o desrespeito pelo corpo feminino é uma manifestação da violência simbólica. Trazemos aqui como referência o conceito de violência simbólica de Bourdieu, que é definida como "violência suave, insensível, invisível a suas próprias vítimas, que se exerce essencialmente pelas vias puramente simbólicas da comunicação e do conhecimento" (LARA et al., p. 164).

As duas canções ressaltam o corpo feminino liberado, pois o eu lírico reivindica sua liberdade. Esse questionamento é notado nessas canções quando elas pedem respeito e pedem que a sociedade permita que as mulheres usufruam da liberdade de andar na rua, pois elas precisam ter o controle do próprio corpo: "Meu corpo, minha lei/Tô por aí, mas não tô a toa/ Respeita, respeita, respeita as mina porra!" (Ana Cañas). Na mesma direção Kell Smith afirma "Que o corpo é nosso, nossas regras/ Nosso direito de ser/ Respeita as mina". 
Com essa postura, a performance feminina de engajamento se destaca na produção das duas canções. Elas pregam um corpo feminino liberado. Dessa forma, a artista contemporânea está alcançando mais espaço para escrever e para externar as suas angústias sobre a opressão que sofrem.

\title{
Primeiro momento da oficina: o que é violência contra a mulher
}

A oficina é aberta com a leitura da letra da canção “Respeita”, de Ana Cañas, que destaca o respeito à mulher e ressalta sua resistência diante das injustiças. Por meio dessa tarefa, tem-se a oportunidade de convidar o/a leitor/a a recepcionar a canção de autoria feminina para ampliar a visão que possui sobre as agressões físicas e simbólicas que a mulher enfrenta em suas atividades corriqueiras. A canção "Respeita" questiona a agressão verbal e física; destaca a coragem da mulher que questiona o desrespeito pelo corpo feminino.

\author{
Respeita(AnaCañas) ${ }^{4}$ \\ Você que pensa que pode dizer o que quiser \\ Respeita, aí! \\ Eu sou mulher \\ Quando a palavra desacata, mata, dói \\ Fala toda errada que nada constrói \\ Constrangimento, em detrimento de todo discernimento quando ela diz não \\ Mas eu tô vendo, eu tô sabendo, eu tô sacando o movimento \\ É covardia no momento quando ele levanta a mão
}

\author{
Ela vai \\ Ela vem \\ Meu corpo, minha lei \\ Tô por aí, mas não tô a toa \\ Respeita, respeita, respeita as mina, porra! \\ $[\ldots]$ \\ Violência por todo mundo \\ A todo minuto \\ Por todas nós \\ Por essa voz que só quer paz
}

${ }^{4}$ Disponível em: https://www.letras.mus.br/ana-caas/respeita/. Acesso em 05 abr. 2018. 


\author{
Por todo luto nunca é demais \\ Desrespeitada, ignorada, assediada, explorada \\ Mutilada, destratada, reprimida, explorada \\ Mas a luz não se apaga \\ Digo o que sinto \\ Ninguém me cala \\ $[\ldots]$
}

Em seguida, passamos à construção do conceito de "empoderamento feminino" de forma subjetiva a partir das experiências dos/as participantes sobre identidade de gênero e opções de profissões para homens e mulheres. Finalizando essa etapa, convidamos para apresentarem suas considerações iniciais a partir do questionário sobre empoderamento feminino:

1. Você já ouviu falar na palavra empoderamento? O que ela significa? E empoderamento feminino do que trata?

2. A mulher tem conquistado muitos espaços na sociedade contemporânea? O que você pensa sobre isso?

3. Homens e mulheres são tratados de forma diferente na sociedade? Como e/ou em quais situações isso pode ser observado?

\title{
Segundo momento da oficina: a performance lírica
}

Neste momento, passamos a leitura da segunda canção desta oficina dando destaque para a performance da artista no videoclipe. Assim, levamos em conta não só o questionamento da violência contra a mulher, mas também a forma como a artista se expressa. No processo interpretativo, a performance da canção anterior também será utilizada como lugar de fala da artista empoderada. 
Respeita as mina (Kell Smith) ${ }^{5}$

Respeita as mina

Toda essa produção não se limita a você

Já passou da hora de aprender

Que o corpo é nosso nossas regras

Nosso direito de ser

Respeita as mina

Toda essa produção não se limita a você

Já passou da hora de aprender

Que o corpo é nosso nossas regras nosso direito de ser

\section{$[\ldots]$}

Não leva na maldade não

Não lutamos por inversão

Igualdade é o "x" da questão, então aumenta o som!

Em nome das marias, quitérias, da penha silva

Empoderadas, revolucionárias

Ativistas, deixem nossas meninas serem super heroínas!

Pra que nasça uma joana d'arc por dia!

Como diria frida: "eu não me kahlo! "

Junto com o bonde saio pra luta e não me abalo

O grito antes preso na garganta já não me consome

É pra acabar com o machismo

E não pra aniquilar os homens

Quero andar sozinha porque a escolha é minha

Sem ser desrespeitada e assediada a cada esquina

Que possa soar bem, correr como uma menina

Jogar como uma menina

Dirigir como menina, ter a força de uma menina

Se não for por mim, mude por sua mãe ou filha!

$[\ldots]$

Assim como na composição de Cañas, a canção "Respeita as Mina”, de Kell Smith, aborda diversas questões sobre o papel da mulher diante da violência. A voz lírica pede que a mulher seja respeitada todos os dias e não apenas no dia 08 de março, Dia Internacional da Mulher. O texto defende o direito de a mulher ser vaidosa, de vestir-se com conforto sem se preocupar em agradar ou chamar a atenção do homem. A liberdade da mulher está acima de dogmas e valores misóginos. Essa performance exalta as mulheres

\footnotetext{
${ }^{5}$ Disponível em: https://www.vagalume.com.br/kell-smith/respeita-as-mina.html Acesso em: 5 abr. 2018.
} 
revolucionárias e ressalta a luta pela igualdade de gênero e pelo fim do machismo. Para isso, reforça que mulheres e homens têm direitos iguais. A mulher tem o mesmo direito do homem de andar sozinha sem sofrer assédio, nem ser considerada culpada por se vestir de forma sensual. Finalizando esta etapa, os/as participantes serão convidados a pontuar elementos semelhantes e diferentes das performances líricas das duas compositoras.

\section{Atividades comparativas das canções}

1. As duas canções trazem uma temática semelhante, pois reivindicam o respeito para com as mulheres. Cite pelo menos dois versos de cada música que ilustram exemplos de desrespeito contra a mulher.

2. As músicas também abordam vários tipos de violência que atingem o público feminino. Releia as letras das músicas e escreva pelo menos dois exemplos de violência física e dois exemplos de violência psicológica que são apresentados nos textos.

3. No contexto da cultura machista, uma das formas de exercer violência contra a mulher é por meio do controle do seu corpo. Comente sobre a liberdade da mulher a partir dos versos selecionados

"Que o corpo é nosso nossas regras/ Nosso direito de ser" (Kell Smith);

"Ela vai/ Ela vem/ Meu corpo, minha lei/ Tô por aí, mas não tô a toa” (Ana Cañas).

4. Como as vozes femininas das músicas representam o empoderamento das mulheres? Justifique com elementos do texto.

\section{Terceiro momento: a recepção cultural}

Nesta fase da oficina foi introduzida a discussão a respeito Lei Maria da Penha. Como na etapa anterior, os/as discentes são convidados a refletirem sobre alguns tipos de crimes e violência contra a mulher. Todos recebem trechos desta lei e são divididos em grupos para realizar a leitura do artigo 7º, que trata da descrição das formas de violência doméstica e familiar contra a mulher. 
LEI MARIA DA PENHA

Art. 7오a formas de violência doméstica e familiar contra a mulher, entre outras:

I - a violência física, entendida como qualquer conduta que ofenda sua integridade ou saúde corporal;

II - a violência psicológica, entendida como qualquer conduta que lhe cause dano emocional e diminuição da autoestima ou que lhe prejudique e perturbe o pleno desenvolvimento ou que vise degradar ou controlar suas ações, comportamentos, crenças e decisões, mediante ameaça, constrangimento, humilhação, manipulação, isolamento, vigilância constante, perseguição contumaz, insulto, chantagem, violação de sua intimidade, ridicularização, exploração e limitação do direito de ir e vir ou qualquer outro meio que lhe cause prejuízo à saúde psicológica e à autodeterminação;

III - a violência sexual, entendida como qualquer conduta que a constranja a presenciar, a manter ou a participar de relação sexual não desejada, mediante intimidação, ameaça, coação ou uso da força; que a induza a comercializar ou a utilizar, de qualquer modo, a sua sexualidade, que a impeça de usar qualquer método contraceptivo ou que a force ao matrimônio, à gravidez, ao aborto ou à prostituição, mediante coação, chantagem, suborno ou manipulação; ou que limite ou anule o exercício de seus direitos sexuais e reprodutivos;

IV - a violência patrimonial, entendida como qualquer conduta que configure retenção, subtração, destruição parcial ou total de seus objetos, instrumentos de trabalho, documentos pessoais, bens, valores e direitos ou recursos econômicos, incluindo os destinados a satisfazer suas necessidades;

$\mathrm{V}$ - a violência moral, entendida como qualquer conduta que configure calúnia, difamação ou injúria (BRASIL, 2006).

Ao finalizar a leitura, os/as participantes passaram a debater em grupo sobre a performances das cantoras e a importância da Lei maria da Penha para a mudança de paradigma da proteção de mulheres que sofrem violência. Esta oficina é concluída com a apresentação de reflexões sobre as canções e os direitos da mulher. No geral, esse debate amplia o horizonte cultural dos/as participantes sobre a violência de gênero. 


\section{A ampliação do horizonte cultural dos/as participantes}

Com a aplicação das oficinas de prática de letramento poético, alcançamos uma expansão do horizonte de expectativa dos/as participantes sobre o empoderamento da mulher, pois houve o desenvolvimento pelo gosto de ler poesias/canções e produção de análise desses textos a partir do lugar de fala dessa comunidade. Essa prática foi aplicada em diversas etapas para uma turma do último ano do ensino fundamental, composta por 17 estudantes, entre 14 e 18 anos, sendo nove do sexo feminino e oito do sexo masculino, equivalendo $53 \%$ de garotas e $47 \%$ de garotos.

Antes de iniciar o debate sobre o tema desta oficina, foram retomadas reflexões das oficinas anteriores em que foram aplicados questionários sobre identidade de gênero e profissões. Para a maioria, as profissões adequadas para as mulheres estão relacionadas a cuidar do outro: professora, enfermeira, entre outras; para os homens as indicadas estão relacionadas à força e às ciências: policial, cientista, jogador de futebol, entre outras. Da etapa anterior, já tinha a constatação que entre os/as participantes prevalecia uma visão preconceituosa em relação à mulher exercer determinadas profissões como jogadora de futebol, motorista de táxi. Nos debates, conseguimos desconstruir o padrão machista, visto que o fato de nascer homem ou mulher, biologicamente falando, não pode servir de parâmetro profissional, pois "muitas vezes usamos a biologia para explicar os privilégios dos homens, e a razão mais comum é a superioridade física masculina” (ADICHIE 2015, p. 23). Assim, restringir e padronizar as atividades das mulheres por questões biológicas faz parte de discursos patriarcais conservadores.

Durante a oficina, destacamos a importância do empoderamento feminino para a mudança de paradigma. Esse debate valorizou o corpo da mulher como um território seu e de liberdade de expressão como destacado pelas compositoras Cañas e Smith. Os/as participantes concordaram que, no cotidiano a mulher tem mais responsabilidade que o homem, pois prevalece a dupla jornada de trabalho para as mulheres, que para tentar alcançar essa ideia de "supermulher", têm que se desdobrarem em várias e, para isso, muitas vezes privam-se até do sono e de cuidar de si mesmas. 
O aspecto da classe social também foi levado em conta em nossa oficina, visto que além de carregar o peso da discriminação em comparação ao homem, a mulher ainda é menos prestigiada se for das classes sociais baixas, ou negras, ou homossexuais, interfaces da desigualdade de gênero, pois "uma mulher negra terá experiências distintas de uma mulher branca por conta de sua localização social, vai experienciar gênero de uma outra forma" (RIBEIRO, 2017, p. 61). Então, a mulher precisa mostrar o poder da sua voz, mas é preciso ter consciência que há muitas barreiras a serem ultrapassadas nessa luta por emancipação e busca pela garantia de direitos e respeito.

No debate, constatamos que "o feminismo precisa ser entendido de forma coletiva e interseccional, porque não há autoestima nesse mundo capaz de derrubar, por si só, um sistema econômico, político e cultural que coloca as mulheres abaixo dos homens" (LARA et al., 2016, p. 75). Nas discussões sobre as performances líricas, houve um engajamento maior das meninas nas atividades de leitura das canções: "Respeita" e "Respeita as mina", que assumiram a leitura, mas no momento do refrão toda a turma lia junto. Conforme essas canções sugerem, a leitura performática foi importante para a aproximação dos/as participantes com o texto lido/declamado em tom de protesto, colocando mais força e eloquência.

Nos comentários compartilhados, esses/as participantes argumentaram que as canções trazem vozes empoderadas, visto que empoderamento das mulheres não é apenas poder, mas também respeito. Em uma das questões foi solicitado que os/as discentes analisassem o videoclipe de cada canção. Eles/as destacaram que o videoclipe da música de Kell Smith "mostra várias mulheres sendo assediadas no dia a dia, como na balada, no trabalho, no ônibus, na academia e todo esse assédio é ocasionado por sua aparência física". As meninas afirmaram que essas cenas realmente são muito comuns também na vida cotidiana delas que, em algumas ocasiões, já se sentiram incomodadas com olhares insistentes e cantadas de mau gosto dirigidas a elas por homens.

Sobre o debate da lei Maria da Penha, sobretudo o artigo 7으, que trata da descrição das formas de violência doméstica e familiar contra a mulher, após a conclusão da leitura e dos debates em grupo, os/ as discentes fizeram a explanação, por meio da oralidade, de cada uma das leis e afirmaram que já 
tinham ouvido falar na lei Maria da Penha, porém nunca havia lido ou discutido nada a respeito. No debate sobre a Lei Maria da Penha, houve o reconhecimento dos avanços da proteção da mulher, mas concordaram que essa lei ainda necessita de melhor adequação à sua implementação naquela região, como destacado por Machado (2017, p. 40).

Após o debate e a finalização das atividades comparando as questões destacadas nas duas canções, os/as participantes ampliaram seu horizonte cultural ao destacarem que as performances femininas dessas artistas traziam também uma postura política. Reconheceram que as canções pedem o respeito pela mulher e abordam alguns tipos de violência que ela sofre na sociedade. Expuseram que já souberam de casos de violência doméstica ocorridos com pessoas próximas a eles/as. Identificaram nas músicas passagens que tratam da violência psicológica e confessaram que já assistiram situações em que a mulher foi constrangida e desrespeitada por namorado ou esposo. Uma discente, que já foi casada, confessou que já sofreu esse tipo de violência.

Por isso, foi fundamental agregar as letras das canções de Kell Smith e Ana Cañas aos videoclipes, pois isso permitiu ampliar a discussão, lembrando que, muitas vezes a mulher sabe dos seus direitos, mas nem sempre tem forças para lutar contra tantas barreiras que o sistema de dominação lhe impõe. Essas músicas também foram essenciais para introduzir o assunto dos direitos da mulher que foi ampliado por meio da inserção de algumas leis que dialogam diretamente com a nossa temática. Isso é importante porque "Nesse desafio, reconhecemos a contribuição teórica da literatura comparada para uma prática cultural de ensino de literatura contemporânea que valorize a formação de um/a leitor/a atualizado/a com a agenda dos direitos da mulher" (GOMES, 2014, p. 13).

Para finalizar a discussão, retomamos aspectos da importância do empoderamento da mulher para o combate à violência de gênero, questionando "o sentimento de posse do homem sobre a mulher, o controle, o abuso, a culpabilização da vítima e a naturalização da violência contra a mulher têm um coeficiente em comum: o machismo enraizado na nossa sociedade, fundada em bases culturais extremamente misóginas" (LARA et al., 2016, p. 192). Isso nos lembra que não há como falar em empoderamento feminino e 
igualdade de gênero sem considerar a estrutura social da qual determinada mulher faz parte.

\section{Considerações finais}

Conforme vimos na análise dos resultados, percebemos por meio da aplicação das oficinas que o imaginário dos/as nossos/as alunos/as mudaram suas opiniões a partir do exercício de leitura e envolvimento com a performance femininas das artistas. Consoante Zumthor, isso acontece porque a recepção dá oportunidade do desenvolvimento de visão privilegiada para o/a leitor/ por meio da performance de leitura, que acontece quando esse sujeito "encontra a obra; e a encontra de maneira indizivelmente pessoal" (2018, p. 49).

Portanto, o processo de leitura subjetiva foi valioso para a formação do/a leitor/a, pois conseguimos despertar o gosto pela leitura ao introduzir temáticas de cunho social. Até mesmo porque "A leitura das obras é, antes de tudo, uma "leitura para si" da qual o sujeito tira o que lhe é necessário para formar seu pensamento e sua personalidade" (ROUXEL, 2013, p. 177). Nessa prática, a preocupação com o empoderamento da mulher despertou o gosto pela leitura e aproximou os/as participantes, que por meio de suas subjetividades agregaram significados novos, ampliando a sua visão de mundo e a sua maneira de enxergar os direitos da mulher.

Desse modo, a ampliação do horizonte cultural dos/as participantes se deu pelo reconhecimento que ainda há desigualdades de gênero e que precisamos superá-las. As análises dos dados colhidos no decorrer da oficina demonstraram o quanto é satisfatório trazer para a sala de aula um tema que possibilite aos/às discentes aprimorarem a criticidade sobre as relações de gênero. Com isso, reconhecemos que ainda há um caminho a ser trilhado para conquistarmos direitos iguais entre homens e mulheres, mas começamos a espalhar as sementes ao ressaltar a importância das performances femininas como resistência social, pois nossa "preocupação e compromisso é semear a poesia. Nem todos os canteiros florescerão, pois há inúmeros empecilhos contra os quais não temos muito o que fazer (ALVES; NEVES, 2017, p. 102). Ao semear a valorização do lugar de fala da mulher, contribuímos para o 
empoderamento das garotas que participaram da oficina e do desenvolvimento do respeito como cantado nas canções analisadas.

\section{Referências}

ADICHIE, C. N. Para educar crianças feministas: Um manifesto. São Paulo: Companhia das Letras, 2017.

ALCÂNTARA, S. S. de. Canção: a poesia nossa de cada dia. Interdisciplinar, São Cristóvão, v. $15, \quad$ p. 23-34, 2012a. Disponível em: https://seer.ufs.br/index.php/interdisciplinar/article/view/1045. Acesso em: 25 mar. 2018.

ALCÂNTARA, S. S. de. Sentidos em todos os sentidos. Recorte revista eletrônica, UNINCOR, v. 09, n. 2, p. 1-16. 2012b. Disponível em: http://periodicos. unincor.br/index.php/recorte/article/view/682/pdf.

Acesso em 30 abr. 2018.

ALVES, J. H. P. Caminhos da abordagem do poema em sala de aula. Graphos. João Pessoa, v. 10, n. 1, p. 19-31, 2008 . Disponível em: https://periodicos.ufpb.br/index.php/graphos/article/view/4299. Acesso em 05 mai. 2018.

ALVES, J. H. P.; NEVES, A. L. M. de S. Vozes femininas da poesia lírica na sala de aula. Interdisciplinar. São Cristóvão, v. 28, p. 91-104, 2017. Disponível em: https://seer.ufs.br/index.php/interdisciplinar/article/view/6838. Acesso em 05 fev. 2018.

BRASIL. Lei Maria da Penha: Lei no 11.340. Brasília: Câmara dos Deputados, Edições Câmara, 2006.

CAÑAS, A. Respeita. Som Livre, 2008.

GOMES, C. M. O leitor cultural. Pontos de Interrogação. Revista de Crítica Cultural da UNEB, Alagoinhas, v. 1, n. 1, p. 08-23, 2011. Disponível em: https://www.revistas.uneb.br/index.php/pontosdeint/article/view/1412. Acesso em: 10 jan. 2019.

GOMES, C. M. O modelo cultural de leitura. Nonada Letras em Revista. Porto Alegre, n. 18, p. 167-183, 2012.

GOMES, C. M. Ensino de Literatura e Cultura: do resgate à violência doméstica. Jundiaí: Paco Editorial, 2014. 
LARA, Bruna de; RANGEL, Bruna; MOURA, Gabriela; BARIONI, Paola; MALAQUIAS, Thaysa. \#Meu amigo secreto: Feminismo além das redes/ [Não me Kahlo]. Rio de Janeiro, 2016.

MACHADO, L. M. Violência contra as mulheres: diálogos entre feminismo e ciência social. In: DIAS A. F.; SANTOS E. F.; CRUZ, M. H. S. (Orgs.). $A$ transversalidade de gênero na produção do conhecimento e nas políticas públicas. Aracaju: Editora IFS, 2017, p. 37-54.

PINHEIRO, Hélder. Poesia na sala de aula. São Paulo: Parábola, 2018.

RIBEIRO, D. O que é: lugar de fala? Belo Horizonte: Letramento, 2017.

ROUXEL, A. Apropriação singular das obras e cultura literária. Tradução de Amaury C. Moraes. In: ROUXEL, A.; LANGLADE G.; REZENDE, N. L. (Orgs.). Leitura subjetiva e ensino de literatura. São Paulo: Alameda, 2013, p. 165-189.

ROUXEL, A. Ensino da literatura: experiência estética e formação do leitor. In: ALVES, J. H. P. (Org.). Memórias da Borborema 4: Discutindo a literatura e seu ensino. Campina Grande: Abralic, 2014, p. 19-35.

SMITH, K. Respeita as mina. Midas Music, 2017.

ZUMTHOR, P. Performance, recepção e leitura. Tradução de Jerusa Pires Ferreira e Suely Fenerich. São Paulo: Ubu Editora, 2018.

Recebido em 29 de abril de 2020.

Aceito em 20 de junho de 2020. 